\title{
Enhancing Creative Thinking Ability of Students in Probability Topics Through React Learning
}

\author{
Dyani Primaningsih $^{1^{*}}$, Wasilatul Murtafiah ${ }^{2}$ \\ ${ }^{1}$ SMAN I Nglames, Jalan Raya Nglames, Madiun 63151, Indonesia. \\ ${ }^{2}$ Pendidikan Matematika, Universitas Negeri Malang \\ *E-mail: dyeprime@gmail.com
}

Article received : June 2019, article revised : Agustus 2019, article published: September 2019

DOI : 10.25273/jipm.v8i1.4443

\begin{abstract}
This study aimed to improve creative thinking ability of students through REACT learning strategy approach in probability topics. REACT learning strategy approach has 5 stages, consist of Relating, Experiencing, Applying, Cooperating, and Transferring. The type of research is Classroom Action Research. The study population was twelfth grade students of SMAN 1 Nglames, and the sample used was one class of XII MIA 2 consist of 32 students. The data collection technique uses (1) test scores of students' creative thinking skills which include the initial and final tests, (2) the results of observations during the learning process, (3) the results of interviews with the subject of the interview. Data were analyzed through descriptive analytic techniques. Based on the data analysis, it was found that each component of creative thinking had the following percentage increase in fluency $(5.22 \%)$, flexibility $(8.81 \%)$, originality $(21.57 \%)$, and elaboration $(29.29 \%)$. The results showed that REACT learning through three stages, namely the initial stage, the core (Relating, Experiencing, Applying, Cooperating, and Transferring), and the closure can improve students' creative thinking skills, especially in the probability topics.
\end{abstract}

Keywords: Creative thinking; Probability; REACT learning

\section{INTRODUCTION}

Based on the 2013 curriculum, one of the life skills that students must develop, and possess during mathematics learning, is the ability to think creatively. With the competence of creative thinking, students will be able to obtain, manage, and use the information to solve problems and even develop divergent thinking and bring up new ideas. The ability to think creatively designed in learning according to William (Margono, 2000) includes aspects of fluency (ability to think smoothly), flexibility (flexible thinking ability), originality (original thinking ability), and elaboration (ability to think in detail). The low ability to think creatively results in students having difficulty solving problems encountered in learning (Mulyasa, 2009).

The results of observations in class XII MIA 2 SMAN 1 Nglames, on the material probability (enumeration rules) show that student learning outcomes are still low, which on average gets 63 with completeness criteria 78. Based on the results of the analysis of problem solving on the probability material are as follows: (1) students have not been able to use the rules of addition, multiplication, permutation, and combination, (2) there are indications that students have 

difficulty solving problems in terms of problemsolving steps, adjusting concepts with the problems encountered and challenges in choosing a strategy of completion. This lack of optimization in solving mathematical problems shows that the ability of students to think creatively in exploring forms of probability problems is still not optimal. The results of research confirm this by Nuriadin \& Perbowo, (2013) which concluded that there is a significant relationship between the ability to think creatively with mathematics learning outcomes.

To optimize the ability to think creatively, then, the learning undertaken must be able to stimulate students' thinking abilities and be able to develop an atmosphere of independent learning. Sumarmo (2005) suggest mathematics learning that encourages creative thinking and higher-order thinking, among others, can be done through learning in small groups, presenting non-routine tasks, and tasks that require students' cognitive and metacognitive strategies. One learning strategy that can develop creative thinking skills, and encourage active student involvement through REACT (Relating, Experiencing, Applying, Cooperating, and Transferring) learning strategies. The REACT strategy provides opportunities for students to be able to do mathematical activities (doing math) through exploration, search, and discovery. Through the discovery that students are actively involved in the process of exploring and empowering thinking skills to create more meaningful and effective learning of critical thinking skills and creative thinking skills (Siburian, Corebima, Ibrohim, \& Saptasari, 2019).

The results of previous studies show that in subjects other than mathematics, namely science, the application of REACT provides effective effects on student learning outcomes (Nelson, Demers, \& Christ, 2014; Ültay, Durukan, \& Ültay, 2015). Learning mathematics with the REACT strategy can improve mathematical communication skills (Herlina, Turmudi, \& Dahlan, 2012), and enhance understanding of mathematical concepts in Geometry material when compared to learning in conventional ways (Jelatu, Sariyasa, \& Made Ardana, 2018). Also, there is a positive relationship between REACT learning with students' critical thinking abilities and mathematical creative abilities (Patimah, 2016).

The results of previous studies indicate that no research reveals the application of REACT learning on the material probability and its effect on students' creative thinking. Based on the problems experienced during the learning process, as well as the results of previous studies, it is expected that through REACT learning the ability of students to think creatively on material probability increases. Thus the novelty of this study is to improve students' creative thinking abilities through the REACT strategy on probability topics.

\section{METHODS}

This type of research is Classroom Action Research (CAR). The approach used in this research is descriptive qualitative because researchers want to obtain in-depth data naturally about REACT learning procedures that can improve students' creative thinking abilities on material probability. The study population was twelfth grade students of SMAN 1 Nglames, and the sample used was one class of XII MIA 2 consist of 32 students. Research data obtained through observation, interviews, documentation, and tests. Observation is used to observe the 
implementation of learning and student activities. While the interview is used to find out the students' responses during the REACT learning and confirm the answers given to the creative thinking questions. The primary data of creative thinking ability is sourced from the results of the pretest, and post-test. The test being tested is in the form of a description test compiled based on indicators of creative thinking ability.

In administering a test score for students' creative thinking abilities, researchers used a scoring guide developed by Bosch (1997). Data validity testing techniques using triangulation techniques. Data analysis techniques using descriptive analysis techniques. Research procedures using Kemmis \& Taggart (1990) include the stages of planning, action, observation, and reflection. The ability to think creatively according to Rahayu, Susanto, \& Yulianti (2011) is divided into five criteria: $81 \%-100 \%$ (very creative category), $617 \%-80 \%$ (creative), 41\%-60\% (quite creative), $21 \%-40 \%$ (less creative), and $<20 \%$ (not creative).

\section{RESULT AND DISCUSSION}

The average score of pre-cycle creative thinking ability is $34.8 \%$. According to the criteria of creative thinking, it can be concluded that the students in class XII MIA 2 are at a less creative level. The solution to the problem of the lack of creative thinking ability of class XII MIA 2 students at SMAN I Nglames is to use the application of REACT. This research was conducted in two cycles, where each cycle consisted of two meetings. The implementation of learning in cycle I can be explained as follows.

The first meeting learning activities (cycle I) are carried out on the material multiplication and permutation rules. The second meeting in the first cycle was held with a combination of material. The implementation of the first cycle consists of three activities, there are opening activities, core activities, and closing activities. The opening activity consists of introduction, apperception, and formulation of learning objectives. In apperception activities, the teacher raises issues related to the prerequisite material. Before entering the core stage, the teacher divides students into heterogeneous learning groups. For learning to run smoothly, and effectively, the teacher explains the tasks and responsibilities of each group member.

The main activity in the first cycle, students work in study groups to solve worksheets that contain creative thinking problems. The relating syntax is done by asking students to write variations of problems in daily life related to the rules of enumeration. Relating students will be better prepared and motivated to participate in learning. In this syntax, students are asked to write problems in everyday life that have many arrangements or ways that might occur as many as 8 ways.

The next stage is students solve a particular problem that allows the emergence of variations of answers and find the nature of the rules of enumeration. At this stage, the experience syntax is visible when students experience the process of discovering and understanding the concept of enumeration rules.

At the Applying stage, students are asked to develop products in the form of varied answers that are in accordance with the real conditions given and understanding the concepts they have. The following is one of the students' answers in solving creative thinking questions that reflect the Applying process. 


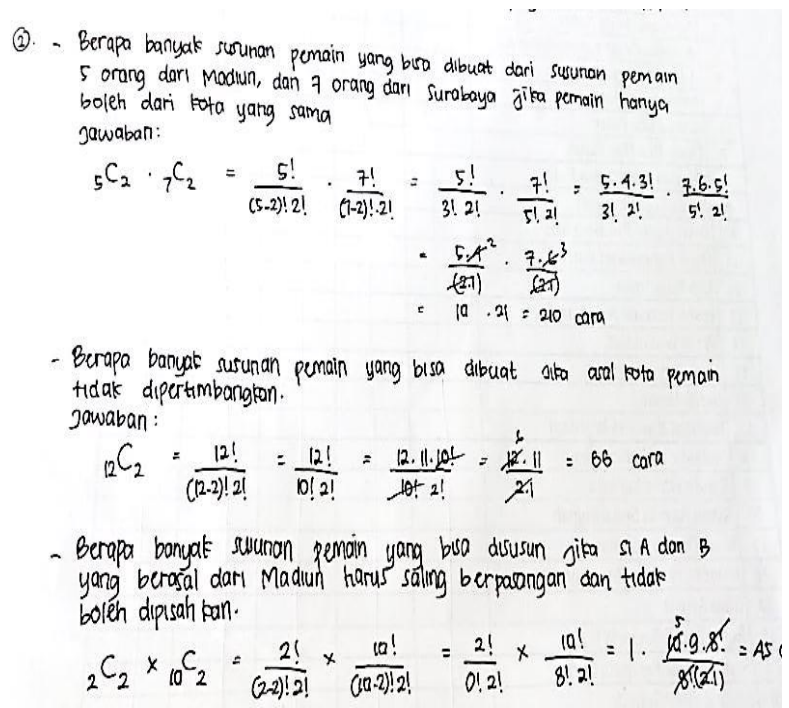

Figure 1. Student Work Results in the Applying Process

Figure 1 shows that students can provide variations of problems and can solve in accordance with the understanding of the combined concepts possessed. The results of the work also illustrate that students can analyze a problem from various points of view. Students can make new rules that new pairs can be from any city, and make a criterion, and certain players must always be in pairs.

The cooperating process of the REACT strategy can be seen when students jointly give, comment on, and refute an opinion, so that common opinion is obtained in solving the problem of creative thinking. From the creative thinking questions contained in the worksheet requires students to provide variations of problems or solutions according to their understanding, as well as their experiences (Transfering).

Closing activities in Cycle I are conducted with, the teacher responds to the discussion and reporting of findings, students and the teacher make conclusions on the learning that has been done, and the teacher evaluates in the form of oral questions, and written. The results of reflection on Cycle I learning that the teacher is too directing students to provide variations of problems or ways of solving. This happens because students are not used to the problem of creative thinking. Another disadvantage of Cycle $I$ is that the learning group activities are only dominated by a few students so that the other members are still passive. Based on the results of reflection in Cycle I, some improvements are needed to implement Cycle II learning.

Learning activities in Cycle II are carried out like Cycle I with some improvements, namely (1) the teacher provides an opportunity for each member in the study group to work independently, (2) the teacher recalls the duties or responsibilities of each group member, as well as supervising, and guiding students who are less active so that all group members take part in completing the assigned tasks. After learning Cycle II is carried out, students work on the posttest questions. The posttest questions are in the form of description items that contain indicators of creative thinking ability.

The results of the analysis of the ability to think creatively at the pretest and posttest found that the students' creative thinking abilities increased from the unfavorable category (38.63\%) to be quite good (56\%). The results of tests of mathematical creative thinking ability for each aspect can be seen in Table 1 . 
JIPM (Jurnal Ilmiah Pendidikan Matematika), 8(1), September 2019- 62

Dyani Primaningsih, Wasilatul Murtafiah

Table 1. Percentage of Every Aspect of Creative Thinking Ability in Pretest and Posttest

\begin{tabular}{ccccc}
\hline & Fluency & Flexibility & Originality & Elaboration \\
\hline Pre-Test & $32 \%$ & $42.86 \%$ & $23.43 \%$ & $25.71 \%$ \\
Postest & $37.22 \%$ & $51.67 \%$ & $45 \%$ & $55 \%$ \\
Peningkatan & $5.22 \%$ & $8.81 \%$ & $21.57 \%$ & $29.29 \%$ \\
\hline
\end{tabular}

The following is a description of every aspect of creative thinking skills:

\section{a. Fluency Aspect}

Indicators of fluency aspects are students able to answer with several answers and submit a variety of problems, and express ideas quickly. The percentage of fluency at the pretest was $32 \%$, while the posttest was $37.22 \%$. The increase from fluency is $5.22 \%$. The fluency aspect is the essential ability students must have to develop flexibility. One way that teachers can develop fluency is to ask questions (Fauziah, 2010). The following is one of the results of student work that reflects fluency in raising problems according to the conditions given.

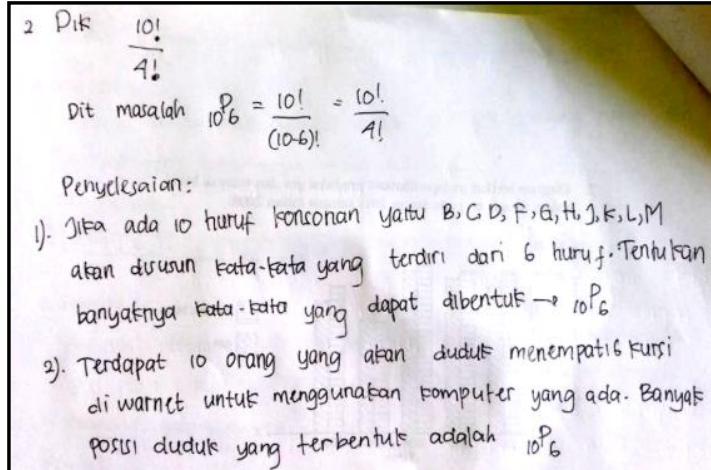

Figure 2. Student Work Results that Reflect Fluency

\section{b. Flexibility Aspect}

The aspect of flexibility is one's ability to produce ideas consisting of different categories or the ability to see an (object, problem) from various points of view (Munandar, 2009). The following is one of the results of student work that reflects flexibility in making different categories according to the conditions given.

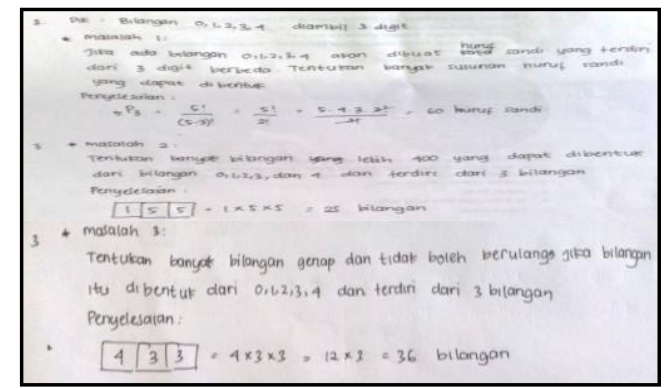

Figure 3. Student Work Results that Reflect Flexibility

The percentage of flexibility at the pretest was $42.86 \%$, while at the posttest was $51.67 \%$. The percentage increase in pretest and posttest was $8.81 \%$. To stimulate students' ability to think flexibly can be done through open or divergent questions (Sumarmo, 2005).

\section{c. Elaboration Aspect}

The elaboration aspect is the ability to propose various problem-solving approaches (Munandar, 2009). The percentage of elaboration pretest was $25.71 \%$ while posttest was $55 \%$. The percentage increase in pretest and posttest was $29.29 \%$. The following is one of the results of student work that reflects flexibility in solving a given problem. In Figure 3 it appears that students can solve problems created by using several concepts simultaneously. The concept in question is the use of multiplication rules and permutation rules.

Elaboration is the aspect with the most percentage. If implemented well, elaboration can 
be a means for students to communicate their work in detail (Filsaime, 2008).

\section{d. Originality Aspect}

According to Filsaime (2008), original thinking is the ability to express ideas or ideas that are unique, and unusual, for example, which are different from those in the book or different from the opinions of others. The development of originality aspects is very related to the aspects of fluency and flexibility. This shows that the percentage of originality at the pretest was $23.43 \%$ while at the posttest was $45 \%$. Large percentage increase in aspects of elaboration is $21,57 \%$.

Based on operational definitions, that the ability to think creatively is said to increase when there is an increase in the classification of students 'creative thinking abilities to be better, the results of the evaluation of learning indicate that REACT learning is effective in increasing students' mathematical creative thinking abilities. The interview results show that students like to carry out REACT learning with challenging variations of creative thinking questions. REACT learning provides opportunities for students to develop creative thinking skills because it involves student activity at each stage.

\section{CONCLUSION}

Based on the results of research conducted, it was concluded that REACT learning that enhances the ability to think creatively is carried out through three activities, namely opening, main, and closing. The opening activity consists of introduction, apperception and formulation of learning objectives. The main activity consists of implementing the five syntaxes in REACT learning, there are Relating, Experiencing, Applying, Cooperating, and Transferring. In implementing REACT, the learning tools used by the LKS are creative thinking. The worksheet used is a matter of description that includes indicators of creative thinking (fluency, flexibility, elaboration, originality). Closing activities carried out with, the teacher responds to the course of discussion and reporting of findings, students and teachers make conclusions on the learning that has been done, and the teacher evaluates in the form of oral questions and written.

Because the ability to think creatively mathematically is needed in mathematics, it is recommended that teachers make improvements to the quality of learning. One of the means of efforts to improve the quality of learning is to conduct research. Similar research that can be done is more specific research, for example, to enhance mathematical creative thinking skills based on gender, or students' initial mathematical abilities. Also, further research can also be developed for critical thinking skills and other higher-order thinking.

\section{REFERENCE}

Bosch, N. (1997). Rubric for Creative Thinking Skills Evaluation. Online. Retrieved from www.adifferentplace. org/creative thinking htm.

Fauziah, A. (2010). Peningkatan Kemampuan Pemahaman dan Pemecahan Masalah Matematika Siswa Melalui Strategi REACT.

Forum Kependidikan, 30(1), 1-13.

Filsaime, D. K. (2008). Menguak Rahasia Berpikir Kritis dan Kreatif. Jakarta: Prestasi Pustaka.

Herlina, S., Turmudi, \& Dahlan, J. A. (2012). Efektivitas Strategi REACT dalam Upaya Peningkatan Kemampuan Komu- 
nikasi Matematis Siswa Sekolah Menengah Pertama. Jurnal Pengajaran MIPA, 17(1), 1-7.

Jelatu, S., Sariyasa, \& Made Ardana, I. (2018). Effect of GeoGebra-aided REACT strategy on understanding of geometry concepts. International Journal of Instruction, 11(4), 325-336. https://doi. org/10.12973/iji.2018.11421a

Kemmis, \& Taggart., M. (1990). The Action Research Planner. Melbourne: Deakin Univercity.

Margono. (2000). Metodologi Penelitian Pendidikan. Jakarta: Rineka Cipta.

Mulyasa. (2009). Menjadi Guru Profesional Menciptakan Pembelajaran Kreatif dan Menyenangkan. Bandung: Remaja Rosdakarya.

Munandar, U. (2009). Pengembangan Kreatifitas Anak Berbakat. Jakarta: Rineka Cipta.

Nelson, P. M., Demers, J. A., \& Christ, T. J. (2014). The responsive environmental assessment for classroom teaching (REACT): The dimensionality of student perceptions of the instructional environment. School Psychology Quarterly, 29(2), 182-197. https://doi.org/10.1037/spq00 00049

Nuriadin, I., \& Perbowo, K. S. (2013). Analisis Korelasi Kemampuan Berpikir Kreatif Matematik Terhadap Hasil Belajar Matematika Peserta Didik Smp Negeri 3 Lurangung Kuningan Jawa Barat. Infinity Journal, 2(1), 65. https://doi.org/10. 22460/infinity.v2i1.25

Patimah, L. (2016). Penerapan Strategi Relating, Experiencing, Applying, Cooperating dan Transfering (REACT) untuk Meningkatkan Kemampuan Berpikir Kritis dan Kreatif Matematis Siswa. UNIVERSITAS PASUNDAN BANDUNG. Retrieved from http:// repository.unpas.ac.id/5184/

Rahayu, E., Susanto, H., \& Yulianti, D. (2011). Pembelajaran Sains Dengan Pendekatan Keterampilan Proses Untuk Meningkatkan Hasil Belajar Dan Kemampuan Berpikir Kreatif Siswa. Jurnal Pendidikan Fisika Indonesia, 7(2), 106-110. https://doi.org/10.15294 /jpfi.v7i2.1081

Siburian, J., Corebima, A. D., Ibrohim, \& Saptasari, M. (2019). The correlation between critical and creative thinking skills on cognitive learning results. Eurasian Journal of Educational Research, 2019(81), 99-114. https://doi.org/10.14 689/ejer.2019.81.6

Sumarmo, U. (2005). Pengembangan Berpikir Matematis Tingkat Tinggi Siswa SLTP dan SMU serta Mahasiswa Strata Satu melalui Berbagai Pendekatan Pembelajaran. Bandung.

Ültay, N., Durukan, Ü. G., \& Ültay, E. (2015). Evaluation of the effectiveness of conceptual change texts in the REACT strategy. Chemistry Education Research and Practice, 16(1), 22-38. https://doi. org/10.1039/c4rp00182f 